\title{
ANALISIS EFEKTIFITAS KEBIJAKAN PEMUTIHAN BEA BALIK NAMA KENDARAAN BERMOTOR DI KOTA MALANG
}

\author{
Achmad Husaini \\ Fakultas Ilmu Administrasi Universitas Brawijaya \\ E-mail : ahusainifia@ub.ac.id
}

\begin{abstract}
The vehicle title transfer fee (BBNKB) is a tax on the submission of the property of a vehicle as a result of two-party agreements or unilateral acts or circumstances that occur due to sale, exchange, grant, inheritance, or income into a business entity. East Java Province as one of the local governments that also collects $B B N K B$ has its own fiscal policy to obtain optimal tax from the motor vehicle sector. The policy is the bleaching of the BBNKB and the release of administrative sanctions for the BBNKB and the Motor Vehicle Tax. So that the bleaching policy on transfer of motor vehicle fees implemented by the Malang City Samsat can be carried out, the policy must be implemented. The focus of this study is the registration mechanism, the calculation mechanism, the payment mechanism and the effectiveness ratio of the acceptance of the BBNKB bleaching policy in 2017 and 2018 in Malang. The results of the study show that the calculation mechanism for tax bleaching every year has been running according to the governor's governing procedures. It only needs to be considered by members of the council so that bleaching can be subject to multilevel tariffs, which have a death tax of more than 10 years, for example sanctions still apply. The effectiveness of this bleaching policy is the ratio of BBNKB revenue in the bleaching period. In 2017, the effectiveness ratio was 110.07\%, which means it had very high effectiveness (>100\%), whereas in 2018 despite decreasing from the previous year which was $107.67 \%$, the achievement fixed to size very effectively.
\end{abstract}

Keywords: Bleaching Policy, Vehicle title transfer fee

\begin{abstract}
ABSTRAKSI
Bea Balik Nama Kendaraan Bermotor atau yang bisa disebut juga BBNKB adalah pajak atas penyerahan hak milik kendaraan bermotor yang disebabkan oleh perjanjian dua pihak atau perbuatan sepihak atau keadaan yang terjadi karena proses jual beli, tukar menukar, hibah, warisan, atau pemasukan ke dalam badan usaha. Provinsi Jawa Timur sebagai salah satu pemerintah daerah yang juga memungut BBNKB memiliki kebijakan fiskal tersendiri untuk memperoleh pajak yang optimal dari sektor kendaraan bermotor. Kebijakan tersebut adalah pemutihan BBNKB serta pembebasan sanksi administratif terhadap nominal yang harus dibayarkan dari BBNKB dan Pajak Kendaraan Bermotor. Agar Kebijakan pemutihan BBNKB yang dilaksanakan oleh Samsat Kota Malang bisa berjalan, maka kebijakan tersebut harus di implementasikan dengan baik dan benar sesuai kaidah kebijakan pemutihan yang berlaku. Fokus penelitian ini adalah mekanisme pendaftaran, mekanisme penghitungan, mekanisme pembayaran dan rasio efektivitas penerimaan kebijakan pemutihan BBNKB tahun 2017 dan tahun 2018 di Kota Malang. Hasil penelitian menunjukkan bahwa mekanisme penghitungan yang dilakukan terhadap pemutihan pajak setiap tahunnya telah berjalan sesuai dengan prosedur peratruran gubernur. Hanya perlu dipertimbangkan anggota dewan agar pemutihan bisa dikenakan tarif bertingkat, yang pajaknya mati diatas 10 tahun misalnya tetap berlaku sanksi. Efektifitas kebijakan pemutihan ini adalah rasio pendapatan BBNKB pada periode pemutihan.Tahun 2017, rasio efektifitas sebesar 110,07\% yang berarti memiliki efektifitas sangat tinggi $(>100 \%)$, sedangkan tahun 2018 walaupun menurun dari tahun sebelumnya yakni 107,67\%, namun capaian tetap pada ukuran sangat efektif.
\end{abstract}

Kata kunci : Kebijakan Pemutihan, Bea Balik Nama Kendaraan Bermotor 


\section{PENDAHULUAN}

Pajak seperti tertulis dalam UndangUndang Nomor 16 tahun 2009 (UU No.16 Tahun 2009) tentang perubahan ke-empat atas Undang-Undang Nomor 6 Tahun 1983 tentang Ketentuan Umum dan Tata Cara Perpajakan pada pasal 1 ayat 1 didefinisikan sebagai suatu kontribusi wajib kepada negara yang terutang oleh orang pribadi atau badan yang bersifat memaksa berdasarkan Undang-Undang, dengan tidak mendapatkan imbalan secara langsung dan digunakan untuk keperluan negara bagi sebesar-besarnya kemakmuran rakyat. Dari definisi tersebut, dapat ditarik kesimpulan bahwa pajak memiliki 4 (empat) unsur (Mardiasmo, 2016). Keempat unsur tersebut adalah (1) Iuran dari rakyat kepada negara ; (2) Berdasarkan Undang-Undang ; (3) Tanpa jasa timbal atau kontraprestasi dari negara secara langsung ; serta (4) Digunakan untuk membiayai rumah tangga negara. Salah satu unsur tersebut menyatakan bahwa Pajak harus dipungut berdasarkan Undang-Undang.

Indonesia memiliki banyak peraturan perundang-undangan yang mengatur tentang perpajakan. Menurut Undang-Undang Nomor 28 Tahun 2009 (UU No.28 Tahun 2009) tentang Pajak Daerah dan Retribusi Daerah, sistem pemerintahan di Indonesia yang menganut sistem otonomi daerah menjadikan penyelenggaraan pemerintahan daerah dilakukan dengan memberikan kewenangan berupa hak dan kewajiban yang seluas-luasnya dalam menyelenggarakan otonomi daerah pada kesatuan sistem penyelenggaraan pemerintahan negara. Salah satu bentuk dari otonomi daerah adalah desentralisasi fiskal. Desentralisasi Fiskal merupakan perubahan peta pengelolaan fiskal yang bergerak dari Pusat ke Daerah (Darwin, 2010). Salah satu perwujudan dari desentralisasi fiskal di Indonesia adalah Undang-Undang Nomor 28 tahun 2009 yang mengatur tentang Pajak Daerah dan Retribusi Daerah.

UU No.28 Tahun 2009 mendefinisikan BBNKB sebagai pajak atas penyerahan hak milik kendaraan bermotor yang disebabkan oleh perjanjian dua pihak atau perbuatan sepihak atau keadaan yang terjadi karena jual beli, tukar menukar, hibah, warisan, atau pemasukan ke dalam badan usaha. Provinsi Jawa Timur sebagai salah satu pemerintah daerah yang juga memungut BBNKB memiliki kebijakan fiskal tersendiri untuk memperoleh pajak yang optimal dari sektor kendaraan bermotor. Kebijakan tersebut adalah pemutihan BBNKB serta pembebasan sanksi administratif bagi BBNKB dan Pajak Kendaraan Bermotor (PKB). Hal tersebut tertuang dalam Peraturan Gubernur Nomor 44 Tahun 2016 (Pergub No.44 Tahun 2016) tentang Pemberian Keringanan dan Pembebasan Pajak Daerah untuk Rakyat Jawa Timur Tahun 2016 dan Tahun 2017. Salah satu asas dalam pemungutan pajak yakni Asas Ease of Administration yang berarti bahwa pajak yang dipungut harus memberikan kemudahan secara prosedur administrasinya bagi Wajib Pajak. Pada prakteknya di lapangan, banyak ditemukan kasus-kasus yang melibatkan Wajib Pajak pada proses pemungutan Pajak Daerah. Salah satu ancaman adalah banyaknya calo yang ada di Kantor Bersama Samsat (Wardana :2015). Calo didefinisikan sebagai orang yang menjadi perantara dan memberikan jasanya dalam proses pengurusan sesuatu berdasarkan upah atau dapat disebut sebagai perantara ataupun makelar (kbbi.go.id, 2015).

Pemungutan BBNKB di Kota Malang pada tahun 2016 merupakan implementasi dari Pergub No.44 Tahun 2016tentang pemutihan Bea Balik Nama Kendaraan Bermotor serta Peraturan Gubernur Jawa Timur Nomor 67 Tahun 2017 (Pergub No.67 Tahun 2017) tentang Pemberian Keringanan, Pembebasan dan Insentif Pajak Daerah untuk Rakyat Jawa Timur Tahun 2017. Kebijakan ini merupakan kebijakan pada lingkup wilayah dan merupakan kebijakan umum yaitu kebijakan Pemerintah Daerah sebagai pelaksanaan azas desentralisasi dalam rangka mengatur urusan Rumah Tangga Daerah. Kebijakan umum lingkup wilayah merupakan wewenang Gubernur dan DPRD Provinsi untuk Daerah Provinsi dan Bupati/Walikota untuk Daerah Kabupaten / Kota. Agar Kebijakan pemutihan BBNKB yang dilaksanakan oleh Samsat Kota Malang bisa berjalan, maka kebijakan tersebut harus di implementasikan.

Penelitian Amelia (2012) menyatakan, bahwa pelaksanaan dan hasil pemutihan BBNKB dan PKB cukup efektif. Hal tersebut dikarenakan berkurangnya potensi tunggakan Pajak Kendaraan Bermotor setelah berlakunya kebijakan tersebut, sedangkan Fristylia (2016) menyatakan terdapat perbedaan yang signifikan sebelum kebijakan pemutihan dan setelah kebijakan pemutihan dilaksanakan terhadap peningkatan penerimaan pajak kendaraan bermotor. 


\section{Tujuan Penelitian}

Tujuan penelitian adalah untuk mengetahui dan menganalisis Efektifitas Kebijakan Pemutihan Bea Balik Nama Kendaraan Bermotor di Kota Malang.

\section{KAJIAN PUSTAKA Pengertian Pajak}

"Pajak adalah peralihan kekayaan dari pihak rakyat kepada kas negara untuk membiayai pengeluaran rutin dan surplus nya digunakan untuk public saving yang merupakan sumber utama untuk membiayai public investment" (Resmi (2014).

Pajak daerah merupakan pajak yang dikelola oleh pemerintah daerah, baik provinsi maupun kabupaten/kota yang berguna untuk menunjang penerimaan pendapatan asli daerah dan hasil penerimaan tersebut masuk dalam APBD (Panca dan Agus, 2006). Pajak daerah dibedakan menjadi dua jenis sebagaimana yang tercantum di UU No.28 Tahun 2009. Berikut merupakan jabaran dari kedua jenis pajak daerah tersebut:

1. Pajak Provinsi yang memiliki jenis pajak sebagai berikut: a) $\mathrm{PKB}$; b) $\mathrm{BBNKB}$; c) Pajak Bahan Bakar Kendaraan Bermotor; d) Pajak Air Permukaan; dan e) Pajak Rokok.

2. Pajak Kabupaten/Kota yang memiliki jenis pajak sebagai berikut: a) Pajak Hotel; b) Pajak Restoran; c) Pajak Hiburan; d) Reklame; e) Penerangan Jalan; f) BPHTB; g) PBB Pedesaan dan Perkotaan; h) Sarang Burung Walet; i) Pajak Air Tanah; j) Mineral Bukan Logam dan Batuan; k) Pajak Parkir

\section{Bea Balik Nama Kendaraan Bermotor (BBNKB)}

UU No.28 Tahun 2009 menjelaskan bahwa Bea Balik Nama Kendaraan Bermotor atau yang bisa disebut juga BBNKB adalah pajak atas penyerahan hak milik kendaraan bermotor yang disebabkan oleh perjanjian dua pihak atau perbuatan sepihak atau keadaan yang terjadi karena proses jual beli, tukar menukar, hibah, warisan, atau pemasukan ke dalam badan usaha

Berdasarkan Peraturan Daerah Provinsi Jawa Timur Nomor 9 Tahun 2010 (Perdaprov Jatim No.9 Tahun 2010) tentang Pajak Daerah bahwa, pelaksanaan pemungutan BBNKB didasarkan tarif yang ditetapkan dikalikan dengan dasar pengenaan BBNKB. Tarif yang ditetapkan adalah sebesar $15 \%$ untuk penyerahan pertama dan $1 \%$ untuk penyerahan kedua dan seterusnya. Khusus untuk Kendaraan Bermotor alat-alat berat dan alat-alat besar tarif BBNKB ditetapkan adalah sebesar $0,75 \%$ untuk penyerahan pertama dan $0,075 \%$ untuk penyerahan kedua dan seterusnya Sedangkan dasar pengenaannya adalah Nilai Jual Kendaraan Bermotor (NJKB) yang berpedoman kepada Peraturan Menteri Dalam Negeri. Subjek pajak dan objek pajak dalam BBNKB adalah orang pribadi dan atau Badan yang dapat menerima penyerahan kendaraan bermotor.

Wajib Pajak BBNKB wajib mendaftarkan penyerahan Kendaraan Bermotor dalam jangka waktu paling lambat 30 (tiga puluh) hari kerja sejak saat penyerahan. Sedangkan orang pribadi atau Badan yang menyerahkan Kendaraan Bermotor melaporkan secara tertulis penyerahan tersebut kepada Kepala Dinas dalam jangka waktu 30 hari kerja sejak saat penyerahan.

Selanjutnya objek pajak BBNKB adalah penyerahan kepemilikan atas Kendaraan Bermotor yang di dalamnya termasuk penyerahan dan pemasukan Kendaraan Bermotor dari luar negeri untuk dipakai secara tetap di Daerah, kecuali:

1. Kendaraan bermotor untuk dipakai sendiri oleh orang pribadi yang bersangkutan;

2. Kendaraan bermotor untuk diperdagangkan;

3. Kendaraan bermotor untuk dikeluarkan kembali dari wilayah pabean Indonesia; dan

4. Kendaraan bermotor digunakan untuk pameran, penelitian, contoh, dan kegiatan olah raga bertaraf Internasional.

Kendaraan Bermotor yang dimaksud dalam pelaksanaan pemungutan BBNKB memiliki beberapa pengecualian diantaranya:1) Kereta api; 2) Kendaraan Bermotor yang semata-mata digunakan untuk keperluan pertahanan dan keamanan negara; 3) Kendaraan Bermotor yang dimiliki dan/atau dikuasai kedutaan, konsulat, perwakilan negara asing dengan asas timbal balik dan lembaga-lembaga internasional yang memperoleh fasilitas pembebasan pajak dari Pemerintah; dan 4) Kendaraan Bermotor yang dioperasikan di air.

\section{Kebijakan}

Pengertian Kebijakan adalah sebagai berikut:

"Kebijakan adalah prinsip atau cara bertindak yang dipilih untuk mengarahkan 
keputusan. Kebijakan senantiasa berorientasi kepada masalah (problemoriented) dan juga berorientasi kepada tindakan (action-oriented), sehingga dapat dinyatakan bahwa kebijakan adalah suatu ketetapan yang memuat prinsip-prinsip untuk mengarahkan cara-cara bertindak yang dibuat secara terencana dan konsisten dalam mencapai tujuan" (Suharto, 2006).

Kebijakan dibedakan menjadi sebagai berikut:

1. Kebijakan Substantif dan Prosedural Substantive Policy berarti merupakan sebuah Kebijakan yang dilihat dari substansi masalah yang dihadapi oleh pemerintah. Sedangkan Procedural Policy Kebijakan dilihat dari pihak-pihak yang terlibat dalam perumusannya (Policy Stakeholder).

2. Kebijakan Distributif, Redistributif dan Regulatory Distributive Policy maksudnya adalah kebijakan yang mengatur tentang pemberian pelayanan/keuntungan kepada individu, kelompok, atau perusahaan. Sedangkan Redistributive Policy Kebijakan yang mengatur tentang pemindahan alokasi kekayaan, pemilikan, atau hak-hak. Terakhir, Regulatory Policy merupakan kebijakan yang mengatur tentang pembatasan/ pelarangan terhadap perbuatan/tindakan.

3. Kebijakan Material. Kebijakan ini merupakan kebijakan yang mengatur tentang pengalokasian/ penyediaan sumber-sumber material yang nyata bagi penerimanya.

4. Kebijakan Barang Publik dan Barang dan Barang Privat. Public Goods Policy adalah kebijakan yang mengatur tentang penyediaan barang/pelayanan oleh pemerintah untuk kepentingan orang banyak. Sedangkan, Private Goods Policy kebijakan yang mengatur tentang penyediaan barang/pelayanan oleh pihak swasta, untuk kepentingan individu di pasar bebas dengan imbalan biaya tertentu.

\section{Kebijakan Pemutihan Bea Balik Nama Kendaraan Bermotor di Kota Malang: Peraturan Gubernur Jawa Timur Nomor 67 Tahun 2017}

Kebijakan pemutihan BBNKB di Jawa Timur merupakan kebijakan yang diturunkan berdasarkan Peraturan Gubernur Jawa Timur Nomor 67 Tahun 2017 tentang Pemberian
Keringanan, Pembebasan dan Insentif Pajak Daerah untuk Rakyat Jawa Timur Tahun 2017. Isi dari Peraturan Gubernur tersebut adalah Pemberian Keringanan oleh pemerintah Provinsi Jawa Timur yang menimbang beberapa hal sebagai berikut:

1. Sebagai upaya meringankan beban masyarakat Jawa Timur dalam melakukan pendaftaran ulang kendaraan bermotor setiap tahun dan Bea Balik Nama Kendaraan Bermotor kedua dan seterusnya serta pemberian Insentif Pajak Kendaraan Bermotor untuk angkutan umum plat dasar kuning yang bertujuan meningkatkan kesadaran masyarakat dalam melakukan pembayaran Pajak Kendaraan Bermotor;

2. Menindaklanjuti ketentuan dalam Pasal 66 Peraturan Daerah Provinsi Jawa Timur Nomor 9 Tahun 2010 tentang Pajak Daerah, tentang perlunya memberikan pembebasan sanksi administrasi terhadap kenaikan dan/atau Bunga Pajak Kendaraan Bermotor, pembebasan pokok dan sanksi administrasi berupa kenaikan dan/atau bunga Bea Balik Nama Kendaraan Bermotor atas penyerahan kedua dan seterusnya serta Insentif Pajak Kendaraan Bermotor untuk angkutan umum plat dasar kuning;

Batang tubuh dari Peraturan Gubernur Nomor 67 Tahun 2017 tersebut apabila ditarik kesimpulan substantif kebijakan pengaturannya adalah sebagai berikut:

1. Pembebasan pokok dan sanksi administrasi terhadap kenaikan dan/atau bunga Bea Balik Nama Kendaraan Bermotor atas penyerahan kedua dan seterusnya;

2. Pembebasan Sanksi Administrasi terhadap kenaikan dan/atau Bunga Pajak Kendaraan Bermotor;

3. Insentif Pajak Kendaraan Bermotor untuk kendaraan bermotor angkutan umum orang dan angkutan umum barang plat dasar kuning sebesar $30 \%$ dari pokok Pajak Kendaraan Bermotor.

\section{Efektivitas}

\section{Pengertian}

"Efektivitas adalah suatu ukuran yang menyatakan seberapa jauh target (kuantitas, kualitas dan waktu) telah tercapai. Dimana makin besar persentase target yang dicapai, makin tinggi efektivitasnya" Hidayat (1986). 
2. Rasio Efektivitas Bea Balik Nama

Kendaraan Bermotor (BBNKB)

Untuk rasio efektivitas Kebijakan Pemutihan BBNKB, dimana rasio ini digunakan untuk menunjukkan kemampuan pemerintah daerah dalam hal ini khususnya Kota Malang untuk mengumpulkan BBNKB sesuai dengan jumlah penerimaan BBNKB yang ditargetkan, maka dapat dihitung dengan rumus sebagai berikut :

$$
\frac{\text { Realisasi Penerimaan BBNKB }(\mathrm{Rp})}{\text { Target Penerimaan BBNKB }(\mathrm{Rp})} \times 100 \%
$$

Untuk pengukuran efektivitas Bea Balik Nama Kendaraan Bermotor (BBNKB) dapat dilihat melalui tabel 2.1 sebagai berikut :

\section{Tabel 1. Pengukuran Efektivitas BBNKB}

\begin{tabular}{|l|l|l|}
\hline No & \multicolumn{1}{|c|}{ Tingkat Pencapaian } & Kategori \\
\hline 1 & Tingkat pencapaian diatas $100 \%$ & Sangat efektif \\
\hline 2 & Tingkat pencapaian antara $90 \%-100 \%$ & Efektif \\
\hline 3 & Tingkat pencapaian antara $80 \%-90 \%$ & Cukup efektif \\
\hline 4 & Tingkat pencapaian antara $60 \%-80 \%$ & Kurang efektif \\
\hline 5 & Tingkat pencapaian di bawah $60 \%$ & Tidak efektif \\
\hline \multicolumn{3}{|c|}{ Sumber : Fristylia (2016) diolah }
\end{tabular}

\section{METODE PENELITIAN}

1. Jenis Penelitian

Jenis penelitian ini tergolong penelitian deskriptif, dimaksudkan untuk mendeskripsikan, menguraikan, dan menginterprestasikan efektivitas kebijakan pemutihan Bea Balik Nama Kendaraan Bermotor (BBNKB) di Kota Malang

2. Fokus Penelitian

Fokus dalam penelitian ini adalah:

a. Mekanisme Pendaftaran

b. Mekanisme Penghitungan

c. Mekanisme Pembayaran

d. Rasio Efektivitas penerimaan kebijakan pemutihan BBNKB tahun 2017 dan tahun 2018

3. Lokasi Penelitian

Penelitian ini dilakukan di Kota Malang Jawa Timur karena memiliki populasi perkembangan kendaraan bermotor yang cukup tinggi seiring dengan tingginya jumlah penduduk Kota Malang.

4. Analisis Data

Metode analisis yang peneliti gunakan adalah teori yang dikemukakan oleh Miles,Huberman,Saldana (2014) yang mengemukakan bahwa aktivitas dalam analisis data kualitatif dilakukan secara interaktif dan berlangsung secara terusmenerus sampai tuntas, sehingga datanya sudah jenuh. Adapun analisis terdiri dari langkah sebagai berikut:
a Collection
b Data Condentation
c Data Display
d Conclusion/drawing

\section{HASIL PENELITIAN}

Pada mekanisme pendaftaran, proses awal pemungutan loket hanya dikelola oleh unit kepolisian yaitu Samsat yang aturan kerjanya telah di atur oleh pusat. Samsat memeriksa keabsahan administrasi di tempat loket pendaftaran, sedangkan Bapenda di tempat loket penetapan untuk menetapkan jumlah pajak BBNKB..

Masyarakat khususnya wajib pajak antusias dengan adanya kebijakan pemutihan ini, hal in dikarenakan untuk menghindari sanksi administratif yang tinggi. Keantusiasan wajib pajak terlihat dari terjadinya penumpukkan antrian. Penumpukkan antrian pendaftaran ini mengakibatkan wajib pajak untuk memilih jalan yang efektif yaitu dengan mengalokasikan sedikit dananya untuk membayar calo. Alasan wajib pajak memilih pakai jasa calo karena malas untuk menunggu antrian dan mobilitas yang tinggi sehingga tdak bisa lama-lama untuk mengantri.

Mekanisme perhitungan, BAPENDA memiliki peran vital yaitu mulai dari menetapkan besaran pajak BBNKB yang dibayar, denda hingga pencatatan penerimaan dan penyetoran pajak ke kas daerah. Tarif untuk pemutihan pajak sudah ditetapkan oleh peraturan gubernur. Perhitungannya dilihat dari berapa tahun pajak kendaraan tersebut mati, kemudian dikalikan sama tarif. Pehitungan besarannya pajak BBNKB untuk pemutihan tersebut tidak membuat wajib pajak marasakan keberatan untuk membayarnya karena sesuai dengan aturan yang telah di tetapkan. Selain itu kebijakan pemutihan BBNKB menjadi daya tarik wajib pajak karena tidak ada sanksi administrasi yang dibayar dan bea balik nama. Mekanisme penghitungan yang dilakukan terhadap pemutihan pajak setiap tahunnya telah berjalan sesuai dengan prosedur peratruran gubernur. Hanya saja munkgin yang perlu dipikirkan oleh anggota dewan adalah pemutihan bisa saja tidak semuanya, mungkin bisa dikenakan tarif bertingkat, yang pajaknya mati diatas 10 tahun misalnya tetap berlaku 
sanksi sekian persen, karena masyarakat sudah semakin sadar pajak, dan itu potensi tambahan daerah harus dimaksimalkan.

Mekanisme pembayaran, dilakukan pengecekan kelengkapan yang selanjutnya ditetapkan melalui Surat Ketetapan Pajak Daerah setelah itu wajib pajak baru bisa membayar pajaknya. Meskipun hanya melakukan pembayaran mekanisme ini merupakan mekanisme yang rumit sehingga sering terjadi kendala teknis internal. Kendala teknis yang sering terjadi adalah masalah koordinasi, hal ini terjadi karena banyak instansi yang terlibat, namun kendala tersebut dapat teratasi. Pada sisi wajib pajak tidak merasakan adanya kendala dalam pembayarannya justru merasakan kemudahan. Kemudahan yang didapatkan wajib pajak adalah tempat antrian menjadi satu tempat pengambilan STNK dan plat nomor.

Ukuran efektifitas kebijakan pemutihan ini adalah rasio pendapatan BBNKB pada periode pemutihan. Diketahui pada tahun 2017, rasio efektifitas adalah sebesar $110,07 \%$ yang artinya memiliki efektifitas sangat tinggi (>100\%), sedangkan pada tahun 2018 meskipun menurun dari tahun sebelumnya yakni $107,67 \%$, namun capaian tetap pada ukuran sangat efektif. Berikut merupakan tabel rasio efektivitas tersebut:

Tabel 2. Rasio Efektivitas Penerimaan Pemutihan BBNKB Kota Malang 2017-2018

\begin{tabular}{|l|l|l|l|c|}
\hline Tahun & Bulan & Target & Realisasi & $\begin{array}{c}\text { Prosentase } \\
\text { Capaian }\end{array}$ \\
\hline 2017 & Desember & $\begin{array}{l}\text { Rp.150.777.0 } \\
90.000\end{array}$ & $\begin{array}{l}\text { Rp.165.971 } \\
.771 .730\end{array}$ & $110,07 \%$ \\
\hline 2018 & Desember & $\begin{array}{l}\text { Rp.180.323.5 } \\
46.000\end{array}$ & $\begin{array}{l}\text { Rp.194.165 } \\
.514 .196\end{array}$ & $107,67 \%$ \\
\hline
\end{tabular}

Kebijakan ini secara rasio efektivitas dapat dikatakan sangat efektif. Namun berdasarkan apa yang pendapat Emerson yang dikutip Handayaningrat (1994) apabila dikaitkan dengan tujuan dari kebijakan tersebut perlu dikaji lebih dalam lagi mengenai kesadaran pajak para wajib pajak BBNKB. Hal ini merujuk pada peraturan gubernur provinsi Jawa Timur nomor 44 Tahun 2016 serta nomor 67 Tahun 2017 mengenai kebijakan pemutihan tersebut, bahwa tujuan utama dari kebijakan tersebut adalah meningkatkan kesadaran membayar pajak kendaraan bermotor dengan cara memberikan insentif. Sehingga meskipun telah tercapai dengan tinggi, namun efektivitas kebijakan belum tentu tercapai apabila kesadaran membayar pajak kendaraan bermotor masyarakat jawa timur masih rendah.

Faktor Pendorong dan Penghambat dalam kebijakan pemutihan Bea Balik Nama Kendaraan Bermotor. Kebijakan pemutihan ini disabut dengan antusias oleh masyarakat yang berbondong-bondong untuk melakukan balik nama. Keantusiasan pemutihan tersebut dikarenakan tidak ada sanksi administrasi dan bea balik nama. Hal ini tentunya menjadi perhatian Samsat Kota Malang untuk membantu mencapai target yang telah ditetapkan. Selama kebijakan pemutihan berjalan terdapat beberapa permasalahan yang menghambat kelangsungan pemutihan. Kejadian yang sering terjadi adalah kelangkapan persyaratan yang dibawa masih kurang lengkap. Seperti mau balik nama harus ada kwintansi jual beli sebagai salah satu persyaratannya. Hal-hal kecil seperti inilah yang sering menjadi faktor penghambat, selain itu sistem yang dijalankan masih manual menjadi faktor penghambat proses pemungutan. Demi menunjang keberhasilan pemutihan pemerintah tidak patang arah dengan berinovasi adanya fasilitas samsat corner, samsat keliling dan payment point. Untuk masyarakat sendiri sekaligus sebagi wajib pajak yang menyebabkan adanya kendala ketika proses pendaftaran diminta mengisi formulir balik nama sehingga menyebabkan antrian panjang, oleh sebab itu wajib pajak berpendapat untuk membedakan loket pengurusan sepeda motor dan mobil agar lebih efektif dan efisien.

Melihat faktor faktor yang menjadi penghambat dan pendorong pada kebijakan pemutihan di Kota Malang tersebut terlihat bahwa faktor struktur birokrasi menjadi persoalan dimana menyebabkan banyak antrian. Pemerintah seharusnya bisa membuat struktur birokrasi menjadi lebih efektif dan efisien seperti inovasi yang pernah dilakukan oleh samsat pada 2 tahun yang lalu ( tahun 2017) dimana terdapat inovasi antrian untuk memecah ramainya antrian. Faktor sruktur birokrasi tersebut juga diperparah dengan faktor sumberdaya dari masyarakat yang kedapatan sering tidak lengkap dalam membawa berkas administratif pemutihan BBNKB.

\section{KESIMPULAN DAN SARAN Kesimpulan}

Kesimpulan dari kebijakan pemutihan Bea Balik Nama Kendaraan Bermotor 
(BBNKB) di Kota Malang telah berjalan dengan sangat efektif berdasarkan rasio efektifitas dimana memiliki capaian 110,07\% pada tahun 2017 dan sebesar $107,67 \%$ pada tahun 2018. Selain itu juga efektivitas dinilai berdasarkan mekanisme berlangsungya kebijakan pemutihan seperti pendaftaran, penghitungan, serta pembayaran.

1. Aspek pendaftaran, belum terlaksana dengan cukup efektif dikarenakan jumlah antrian setiap tahunya selalu banyak, sehingga perlu dilakukan inovasi terhadap antrian agar dapat mengurangi banyaknya Calo.

2. Aspek penghitungan, semuanya telah berjalan sesuai dengan peraturan gubernur yang ditetapkan, hanya saja melihat potensi yang ada saat ini maka kedepanya harus dilakukan penetapan tarif pemutihan berdasarkan lamanya mati pajak dari kendaraan tersebut.

3. Aspek pembayaran, biasanya hanya terjadi permasalahan koordinasi antar instansi dalam samsat dan dapat diselesaikan. Pada agenda pemutihan tidak ada kendala berarti, telah cukup diantisipasi.

2. Faktor pendorong suksesnya pelaksanaan kebijakan pemutihan BBNKB adalah disambut dengan antusias oleh masyarakat yang berbondong-bondong untuk melakukan balik nama.

3. Faktor penghambat kelangkapan persyaratan yang dibawa masih kurang lengkap, seperti untuk balik nama harus ada kwintansi jual belinya sebagai salah satu persyaratannya.

\section{Saran}

Berdasarkan kesimpulan dari penelitian, maka diajukan beberapa saran sebagai berikut :

Pemerintah harus dapat tetap mempertahankan efektivitas kebijakan pemutihan BBNKB yang dilaksanakan di Kota Malang. Pemerintah Provinsi Jawa Timur juga perlu mempertimbangkan untuk mengklasifikasikan tarif pemutihan .

Masyarakat sebagai wajib pajak kendaraan bermotor harus lebih memahami peraturanperaturan mengenai pemutihan BBNKB setiap tahunya.

\section{DAFTAR PUSTAKA}

Darwin. 2010 . Pajak Daerah dan Retribusi Daerah. Jakarta: Mitra Wacana Media

Handayaningrat, Soewarno. 1994. Pengantar Ilmu Administrasi dan Manajemen. Jakarta: NV. Sapdodadi

Hidayat. 1986. Teori Efektifitas Dalam Kinerja Karyawan. Yogyakarta: Gajah Mada University Press.

KBBI. 2015. Arti Kata Calo. Diakses melalui http://kbbi.co.id/arti-kata/calo pada tanggal Senin 1 Mei 2017

Mahmudi. 2010. Manajemen Keuangan Daerah. Yogyakarta: Erlanggga

Mardiasmo. 2016. Perpajakan Edisi Terbaru 2016. Yogyakarta: ANDI Yogyakarta

Moleong, Lexy. 2014. Metodologi Penelitian Kualitatif (Edisi Revisi). Bandung: PT. Remaja Rosdakarya.

Nugroho, Riant. 2012. Public Policy: Dinamika Kebijakan, Analisis Kebijakan, Manajemen Kebijakan. Jakarta: Elex Media Komputindo.
Panca, Kurniawan \& Agus Purwanto.2006.Pajak Daerah \& Retribusi Daerah di Indonesia.Malang: Bayumedia

Peraturan Gubernur Jawa Timur Nomor 44 Tahun 2016 tentang Pemberian Keringanan Dan Pembebasan Pajak Daerah Untuk Rakyat Jawa Timur Tahun 2016

Peraturan Presiden Nomor 5 Tahun 2015 tentang Penyelenggaraan Sistem Administrasi Manunggal Satu Atap Kendaraan Bermotor

Resmi, Siti. 2014. Perpajakan (Teori dan Kasus). Jakarta: Salemba Empat

Rosdiana, Haula dan Rasin Tarigan. 2005. Perpajakan Teori dan Aplikasi. Jakarta: Raja Grafindo

Santoso, Singgih. 2004. Buku Latihan SPSS Statistik Parametrik. Jakarta: PT Elex Media Komputindo.

Sidik, Machfud. 2002. Format Hubungan Keuangan Pemerintah Pusat dan Daerah yang Mengacu pada Pencapaian Tujuan 
Nasional. Seminar Nasional public sector score card, Jakarta, 2002

Simanjuntak, Timbul Hamonangan dan Imam Mukhlis. 2012. Dimensi Ekonomi Perpajakan Dalam Pembangunan Ekonomi. Jakarta: Raih Asa Sukses

Sugiyono. 2011. Metode Penelitian Kuantitatif, Kualitatif, dan Kombinasi (Mixed Methods). Bandung: Alfabeta

Suharno. 2003. Pengelolaan Pajak Bumi dan Bangunan dalam Era Otonomi Daerah. Direktorat PBB dan PBHTB: Jakarta

Sumarsan, Thomas. 2014. Perpajakan Indonesia. Jakarta Barat: PT.Indeks

Undang-Undang Nomor 16 tahun 2009 tentang Ketentuan Umum dan Tata Cara Perpajakan

Undang-Undang Nomor 28 tahun 2009 tentang Pajak Daerah dan Retribusi Daerah 